\title{
Indigenous practices in poultry farming using maggots in western Burkina Faso
}

\author{
A.G. Sanou $^{1 *}$, F. Sankara ${ }^{1}$, S. Pousga ${ }^{1}$, K. Coulibaly ${ }^{1}$, J.P. Nacoulma ${ }^{1}$, M. Kenis ${ }^{2}$, V.A. Clottey ${ }^{3}$, S. Nacro ${ }^{4}$, I. Somda ${ }^{1}$ \\ and I. Ouédraogo 4 \\ ${ }^{1}$ Institut du Développement Rural (IDR), Université Nazi Boni, 01 P.O. Box 1091, Bobo-Dioulasso, Burkina Faso; ${ }^{2}$ Centre \\ for Agriculture and Biosciences International (CABI), 1 Rue des Grillons, Delemont, Switzerland; ${ }^{3}$ Centre for Agriculture \\ and Biosciences International (CABI), 6 Agostino Neto Road, CSIR Campus, Accra, Ghana; ${ }^{4}$ Institut de l'Environnement \\ et de Recherches Agricole (INERA), 01 P.O. Box 910, Bobo-Dioulasso, Burkina Faso; sanougafar10@gmail.com
}

Received: 29 December 2017 / Accepted: 27 July 2018

(c) 2018 Wageningen Academic Publishers

OPEN ACCESS CC) RES(-) REARCH ARTICLE

\begin{abstract}
The exploitation of insects such as saprophagous fly larvae for poultry nutrition is getting prominence in many African countries. In the framework of a participatory research, a survey was carried out in Burkina Faso to assess the present use of fly larvae and other feed inputs in traditional poultry farming, to identify traditional methods associated with fly larvae production and to gather information on the organic wastes that could be used locally by farmers to produce fly larvae. A questionaire was randomly administered to 360 poultry farmers in 12 villages and 2 regions (Boucle du Mouhoun and Hauts-Bassins) in Burkina Faso. Nearly 15\% of the respondents mentioned that they also use fly larvae at least occasionally. Fly larvae are either produced by exposing substrates to naturally occurring flies, in which case larvae are obtained after three to 14 days, depending on the species, or directly collected in organic wastes. Housefly (Musca domestica L.) was the most commonly used fly species but black soldier fly (Hermetia illucens (L.)) was also cited by some farmers. Over 30 organic wastes of animal or plant origin were cited by farmers as substrates that can attract adult flies and allow the development of their larvae. Farmers who have already produced fly larvae cited 25 potential substrates that can be used either alone or mixed with attractants. Information was gathered on the production techniques and their constraints, among which the lack of availability of suitable substrates. The study highlighted the potential of maggots as protein feed in traditional poultry farming but also the need to develop sustainable, efficient and safe production methods. The survey revealed the need to determine the most productive substrates for maggot rearing and safe substrates for poultry health. There are also indigenous practices that can be improved to increase maggot production.
\end{abstract}

Keywords: bird feed, fly larvae production, Hermetia illucens, Musca domestica

\section{Introduction}

The poultry sector in sub-Saharan Africa is subject to many constraints of health, food and socio-economic factors (Ayssiwede et al., 2013; Boko et al., 2006; FAO, 2008). Among the difficulties highlighted, obtaining sustainable protein sources for feed is a major constraint in poultry farming (Dahouda et al., 2009; Pousga and Boly, 2009). This issue is particularly severe in Burkina Faso, where nearly all smallholder farmers hold scavenging poultry, which usually suffers from a recurring lack of proteins, causing slow growth and high juvenile mortality (FAO, 2008; Ouattara et al. 2014; Pousga et al., 2005). One alternative to these difficulties may be the use of unconventional sources such as insects (Kenis et al., 2014; Makkar et al., 2014; Ouédraogo et al., 2015b; Van Huis et al., 2013). Indeed, the use of insects as animal feed is increasingly promoted in many African countries (Barre et al., 2014; Boko et al., 2006; Bouafou, 2011; Bouafou et al., 2006; DGESS, 2015; Pomalégni et al., 2016, 2017). Insects are safe, very nutritious (protein, minerals, etc.) and can therefore improve poultry's health (Van Huis et al., 2013). In addition, the wild collection and rearing of these insects requires a low level of technology and limited investment (Van Huis et al., 2013). Thus, the exploitation of insects could be adapted to both urban and rural environments (Van Huis et al., 2013). In Burkina 
Faso, as in many other West African countries, insects such as maggots, termites, caterpillars and locusts are used in protein nutrition of poultry in rural areas (Ayssiwede et al., 2013; Kenis et al., 2014; Ouédraogo et al., 2015a). Among these insects, the larvae of saprophagous flies such as the house fly (Musca domestica L.) and the black soldier fly, Hermetia illucens (L.) show much potential. During their developmental cycle, the immature stages of these flies feed and grow rapidly on decomposing organic residues. The maggots then mobilise nutrients that the birds could use as protein source (Loa, 2000). This re-use of organic waste constitutes a new valorisation of these resources. For example, the seed meal of Jatropha curcas (biodiesel waste and oil extraction waste) has been successfully tested in Benin as a substrate for the production of larvae of the house fly (Pomalégni, 2017).

In Burkina Faso, saprophagous fly larvae, mainly house fly but also blow flies (Calliphoridae) are traditionally obtained by collecting them in wastes or by voluntarily exposing substrates to attract adult flies (Hardouin and Mahoux, 2003; Hien et al., 2005; Ouédraogo et al., 2015b; Pousga, 2007; Pousga and Boly, 2009). The natural oviposition technique for the production of maggots has been recently tested and assessed at semi-industrial farmer scale (Koné et al., 2017; Roffeis et al., 2017). However, so far, few attempts have been made to quantitatively assess and describe the traditional practices of maggot productions of smallholder farmers, with the exception of Pomalégni et al. (2017) in Benin. This study is part of a participatory research with a view to improve the identified indigenous techniques of producing fly larvae for feeding poultry. For this, it is necessary to take stock of indigenous practices and substrates (organic residues) available to successfully produce maggots (Kenis et al., 2014; Koné et al., 2017; Loa, 2000; Odesanya et al., 2011; Ouédraogo et al., 2015b; Zhou et al., 2013). The objective of this study was to identify the indigenous practices associated with the production of maggots in Western Burkina Faso and to identify organic wastes that can be reused on-farm by poultry farmers to produce maggots.

\section{Materials and methods}

\section{Study area}

The survey was carried out in the Boucle du Mouhoun (BM) and Hauts-Bassins $(\mathrm{HB})$ regions. The administrative centres of these regions are respectively Dedougou $\left(12^{\circ} 28^{\prime} \mathrm{N}\right.$ and $\left.3^{\circ} 28^{\prime} \mathrm{W}\right)$ and Bobo-Dioulasso $\left(11^{\circ} 12^{\prime} \mathrm{N}\right.$ and $\left.4^{\circ} 18^{\prime} \mathrm{W}\right)$. These two regions were chosen considering their importance in poultry farming in Burkina Faso (DGESS, 2015). In 2014, poultry production was approximately $5,278,000$ birds and $5,122,000$ birds in BM and HB, i.e. the $2^{\text {nd }}$ and $3^{\text {rd }}$ most productive regions of the country, respectively (DGESS, 2015). The main socio-economic activity of farmers in the two regions is subsistence farming. The majority of farmers practices both agriculture and livestock farming. The BM region is located in the Sudano-sahelian zone in which the rainfall varies between 600 and $900 \mathrm{~mm}$ over 4 to 5 months. The average monthly temperature varies between 26 and $33{ }^{\circ} \mathrm{C}$. This region is characterised by a vegetation of savanna and graminaceous annual shrubs. In the $\mathrm{HB}$ region, the rainy season lasts 5 to 6 months with an annual rainfall of about 1,100 mm annually (Sudanese zone). The average monthly temperature varies between 25 and $30{ }^{\circ} \mathrm{C}$. Most parts of the HB region are covered by a wooded savannah, shrub savannah and grass savannah (Thiombiano and Kampmann, 2010).

\section{Inventory and analysis of indigenous practices of maggot use in poultry nutrition}

A questionnaire pre-testing was carried out in the town of Bobo-Dioulasso and in one of the target villages in order to inspire and improve the design of the questionnaire. Then, nine provinces and 12 villages (six villages per region) were selected for the interviews, carried out by the first author (Figure 1). The villages were chosen primarily according to the number of their inhabitants, i.e. those with the largest numbers of inhabitants (INSD, 2008). However, they were also chosen on different roads, with a view to have geographical diversification of the target villages. The sample size was set at 360 households in the two regions (180 by region). Thirty poultry farmers selected randomly in each of the 12 villages. All households interviewed during this survey owned their poultry flock. The 12 villages were: Bama, Di, Djibasso, Fara, Founzan, Gombeledougou, Karankasso-sambla, Kouka, Kourinion, Kourouma, Safane, and Yaba.

The questionnaire was part of a large participatory research carried out in the framework of the project IFWA (see acknowledgements) that assessed the poultry farmers perceptions for production and use of insects as poultry feed. The whole set of questions used in this study are listed in Supplementary Material S1. They concerned the feed components given to poultry in general, the knowledge of the fly larvae and of the use of these larvae as poultry feed, details of the use and production of fly larvae, in particular the substrate use for the production and the availability of suitable substrates.

\section{Data management and statistics}

Statistical analyses were carried out using IBM SPSS Statistics software version 22 (IBM, Armonk, NY, USA). The following data were compared using Pearson's chi-square tests at the probability threshold of 5\%: feed inputs and their relative importance in avian nutrition, potential substrates/ attractants and their utilisation in maggot production in the two investigated regions. The comparison of proportions 


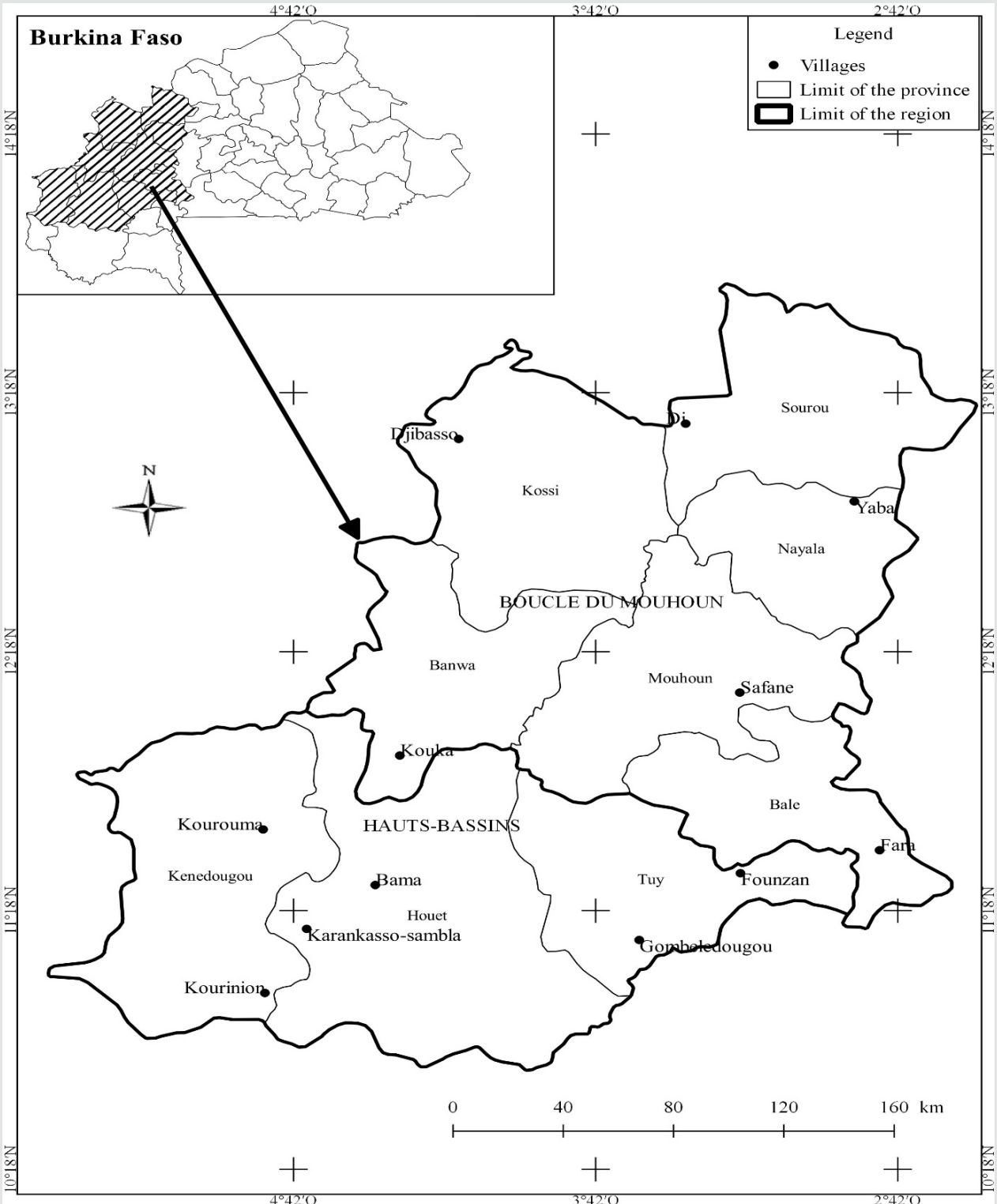

Figure 1. Geographical distribution of surveyed villages in western Burkina Faso.

between feed inputs and the two regions was adjusted using the Bonferroni method.

The methods used for calculating percentages were as follows:

Availability of each

substrate attractant

by region $(\%)=\underline{\text { number of respondents } \times 100}$

180

With 180 as the number of surveyed by region.
Proportion of use of each

substrate and/or attractant number of respondents $\times 100$ by region $(\%)=\frac{\text { number of respont }}{180}$

Proportion of use of each number of respondents $\times 100$ feed input $(\%)=\frac{\text { number }}{360}$

With 360 as the total number of surveyed. 


\section{Results}

\section{Importance of feed inputs in traditional poultry feed}

Avian feed is highly diversified in rural areas, and takes into account, in particular, the availability of cereals and the economic conditions of poultry farmers. Feed inputs and their relative importance in avian nutrition are presented in Figure 2. Cereal grains followed by cereal brans represented the main feed used by farmers. The protein sources commonly used by respondents were fishmeal (included in 'other foods' in Figure 2), termites and maggots. All surveyed farmers were aware of the use of termites as poultry feed. However, these insects were mostly used either as occasional or regular feed supplement. Only $4.1 \%$ used maggots rather regularly as secondary or complementary feed and $10.8 \%$ of poultry farmers used them occasionally. None of them ever bought larvae.

\section{Substrates available and used for fly larvae production}

A total of 34 potential substrates and/or attractants were identified among respondents, either because they are used for fly larvae production or collection, or because farmers have observed larvae developing in them. These were mostly organic residues of animal, plant and mixtures. Table 1 shows the availability and use of the cited substrates. Availability refers to the percentage of poultry farmers who have at their disposal an organic waste on their farm. It does not consider access to these residues in the light of multiple and complex social considerations. Most of these residues are also used for various purposes such as organic fertilisers in crop production or as feed for poultry and other animals and, thus, may not be favoured for fly larvae production. Significant differences are observed between the two regions $\left(\chi^{2}=118.657 ; \mathrm{df}=32 ; P<0.001\right)$. However, only three main substrates were identified as the most available in both regions. These were poultry manure with or without litter (from chicken, guinea fowl, turkey, duck, geese); kitchen waste and food left-overs; and maize bran (Table 1, column availability of substrates/ attractants). Other available substrates are cattle, sheep and goat manures with or without litter collected from the animal pens.

Producers and collectors of maggots use a variety of organic residues (Table 1 , column 'Utilisation of substrates/ attractants'). The most used organic waste was animal blood, residues of traditional brewery waste, shea fruit (Vitellaria paradoxa) pulp (Hauts-Bassins) and the rumen

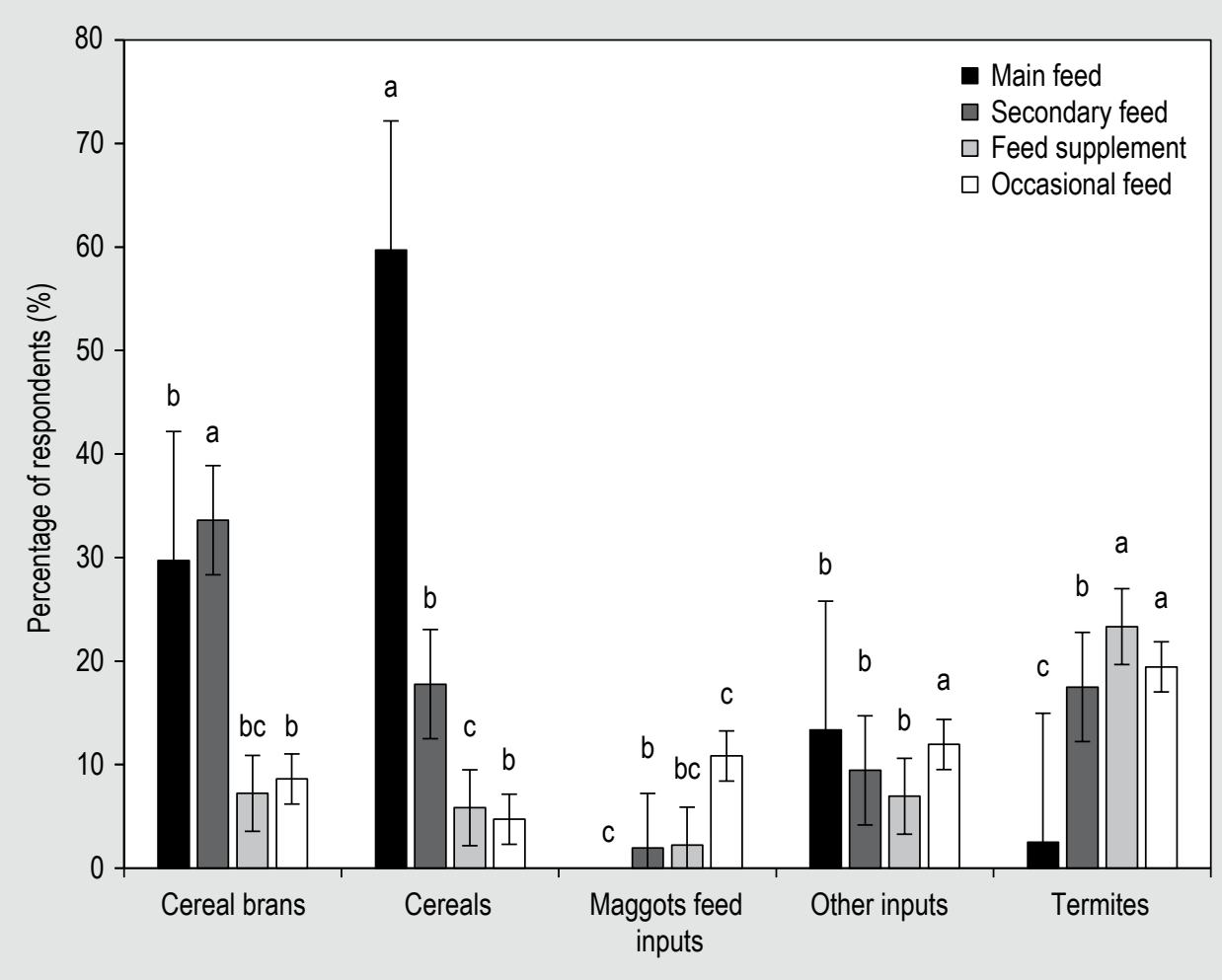

Figure 2. Feed inputs and their relative importance in avian nutrition. 'Maggots' include both situations, i.e. when they are produced voluntarily by the farmer and/or collected in decomposing organic residues. The category of feed input (main feed, secondary feed, feed supplement, occasional feed) was given by the farmer according to the frequency and the quantity given to poultry. Each feed input appears once by respondent and by feed category. Per category, feed inputs followed by the same letter are not statistically different at 0.05 level (Pearson's chi-square tests; $X^{2}=427,682 ; \mathrm{df}=12 ; P<0.001$ ). The lines above bars are standard errors. 
Table 1. In the two regions ${ }^{1}$, percentage of respondents who cited a potential substrate/attractant as being available on farm (availability of substrates/attractants) and who use or have used these substrates/attractants to produce or collect fly larvae for poultry feed (utilisation of substrates/attractants).

\begin{tabular}{|c|c|c|c|c|c|c|c|c|c|}
\hline \multirow{3}{*}{$\begin{array}{l}\text { Categories of } \\
\text { substrates and/ } \\
\text { or attractants }\end{array}$} & \multirow[t]{3}{*}{$\begin{array}{l}\text { Potential substrates and/or } \\
\text { attractants }\end{array}$} & \multicolumn{4}{|c|}{$\begin{array}{l}\text { Availability of substrates/attractants } \\
(n=360)\end{array}$} & \multicolumn{4}{|c|}{$\begin{array}{l}\text { Utilisation of substrates/attractants } \\
(n=360)\end{array}$} \\
\hline & & \multicolumn{2}{|c|}{$\begin{array}{l}\text { Frequencies of } \\
\text { respondents }\end{array}$} & \multicolumn{2}{|c|}{$\begin{array}{l}\text { Proportion of } \\
\text { respondents (\%) }\end{array}$} & \multicolumn{2}{|c|}{$\begin{array}{l}\text { Frequencies of } \\
\text { respondents }\end{array}$} & \multicolumn{2}{|c|}{$\begin{array}{l}\text { Proportion of } \\
\text { respondents }(\%)^{2}\end{array}$} \\
\hline & & BM & HB & BM & HB & BM & HB & BM & HB \\
\hline \multirow[t]{9}{*}{ Manures } & poultry manure $\pm^{3}$ litter & 180 & 180 & 100 & 100 & 1 & 0 & 0.6 & 0.0 \\
\hline & pigeon droppings \pm litter & 20 & 17 & 11.1 & 9.4 & 0 & 0 & 0.0 & 0.0 \\
\hline & cattle manure \pm litter & 132 & 118 & 73.3 & 65.6 & 2 & 7 & 1.1 & 3.9 \\
\hline & sheep manure \pm litter & 129 & 101 & 71.7 & 56.1 & 1 & 0 & 0.6 & 0.0 \\
\hline & goat manure \pm litter & 115 & 106 & 63.9 & 58.9 & 1 & 1 & 0.6 & 0.6 \\
\hline & pig manure \pm litter & 38 & 19 & 21.1 & 10.6 & 0 & 2 & 0.0 & 1.1 \\
\hline & rabbit manure \pm litter & 5 & 4 & 2.8 & 2.2 & 0 & 0 & 0.0 & 0.0 \\
\hline & human manure & - & - & - & - & 0 & 2 & 0.0 & 1.1 \\
\hline & biogas effluent & 1 & 1 & 0.6 & 0.6 & 0 & 1 & 0.0 & 0.6 \\
\hline \multirow[t]{6}{*}{ Slaughter wastes } & cattle rumen content & 1 & 4 & 0.6 & 2.2 & 19 & 6 & 10.6 & 3.3 \\
\hline & sheep rumen content & 1 & 3 & 0.6 & 1.7 & 12 & 6 & 6.7 & 3.3 \\
\hline & goat rumen content & 0 & 3 & 0.6 & 1.7 & 13 & 6 & 7.2 & 3.3 \\
\hline & pig offal & 0 & 2 & 0.0 & 1.1 & 1 & 1 & 0.6 & 0.6 \\
\hline & animal blood & 1 & 1 & 0.6 & 0.6 & 14 & 5 & 7.8 & 2.8 \\
\hline & fish offal and scales & 11 & 1 & 6.1 & 0.6 & 6 & 0 & 3.3 & 0.0 \\
\hline \multirow[t]{7}{*}{ Mixed cereal bran } & kitchen waste and food left-overs & 179 & 177 & 99.4 & 98.3 & 0 & 4 & 0.0 & 2.2 \\
\hline & millet bran & 59 & 46 & 32.8 & 25.6 & 0 & 1 & 0.0 & 0.6 \\
\hline & maize bran & 125 & 151 & 69.4 & 83.9 & 2 & 2 & 1.1 & 1.1 \\
\hline & sorghum bran & 60 & 49 & 33.3 & 27.2 & 0 & 1 & 0.0 & 0.6 \\
\hline & fonio bran & 0 & 19 & 0.0 & 10.6 & 0 & 0 & 0.0 & 0.0 \\
\hline & rice bran & 40 & 65 & 22.2 & 36.1 & 1 & 1 & 0.6 & 0.6 \\
\hline & wheat bran & 4 & 2 & 2.2 & 1.1 & 0 & 0 & 0.0 & 0.0 \\
\hline \multirow{9}{*}{$\begin{array}{l}\text { Agro-industrial } \\
\text { waste }\end{array}$} & cottonseed cake & 11 & 4 & 6.1 & 2.2 & 0 & 1 & 0.0 & 0.6 \\
\hline & cotton ginnery waste & 30 & 61 & 16.7 & 33.9 & 0 & 2 & 0.0 & 1.1 \\
\hline & traditional brewery waste & 34 & 28 & 18.9 & 15.6 & 11 & 7 & 6.1 & 3.9 \\
\hline & $\begin{array}{l}\text { filtrate from the fermentation of } \\
\text { Parkia biglobosa seeds }\end{array}$ & 2 & 6 & 1.1 & 3.3 & 0 & 1 & 0.0 & 0.6 \\
\hline & $\begin{array}{l}\text { filtrate from the fermentation of } \\
\text { Hibiscus sabdariffa seeds }\end{array}$ & 4 & 2 & 2.2 & 1.1 & 0 & 0 & 0.0 & 0.0 \\
\hline & sludge from shea butter processing & 0 & 2 & 0.0 & 1.1 & 0 & 0 & 0.0 & 0.0 \\
\hline & shea fruit (Vitellaria paradoxa) pulp & 7 & 20 & 3.9 & 11.1 & 8 & 11 & 4.4 & 6.1 \\
\hline & cottonseed cake & 11 & 4 & 6.1 & 2.2 & 0 & 1 & 0.0 & 0.6 \\
\hline & cotton ginnery waste & 30 & 61 & 16.7 & 33.9 & 0 & 2 & 0.0 & 1.1 \\
\hline \multirow[t]{4}{*}{ Fermented fruits } & rotten mango fruits from orchards & 13 & 25 & 7.2 & 13.9 & 0 & 0 & 0.0 & 0.0 \\
\hline & rotten cashew fruits from orchards & 3 & 28 & 1.7 & 15.6 & 0 & 0 & 0.0 & 0.0 \\
\hline & rotten papaya fruits from orchards & 0 & 1 & 0.0 & 0.6 & 0 & 0 & 0.0 & 0.0 \\
\hline & rotten banana fruits from orchards & 3 & 8 & 1.7 & 4.4 & 0 & 2 & 0.0 & 1.1 \\
\hline Others & vegetable garden wastes & 75 & 41 & 41.7 & 22.8 & 0 & 1 & 0.0 & 0.6 \\
\hline
\end{tabular}


contents of cattle, sheep, and goat. Animal blood, rumen contents of cattle, sheep, and goat were the most used although they are very scarce substrates on farm $(<3 \%)$. A significant difference of utilisation between the regions was observed only for cattle rumen content $\left(\chi^{2}=16.463\right.$; $\mathrm{df}=7 ; P<0.001)$.

\section{Practices related to the production of maggots}

A variety of substrates and methods were noted among these poultry producers. Each technique uses a base substrate that is sometimes mixed with other substrates (Table 2). Substrates were initially obtained in various levels of humidity and this determines the amounts of water to add to it.

Poultry farmers reported the use of attractants to enhance egg-laying and reduce the number of production days. They further pointed that these attractants contributed to increase in maggot yield. However, in general, production substrates were often used without an attractant. The number of production days fluctuated from three to more than ten days. Poultry farmers, however, pointed out that the size of maggots was fairly small on the $3^{\text {rd }}$ day. This prompted some to observe additional days to increase production (Table 2). Variations in daylength were also related to different fly species. For example, the 14 days mentioned for the mixture including traditional brewery waste probably refers to black soldier flies.

The larvae were produced in several containers such as clay pots, calabashes, buckets, cans, basins and even on the ground. Among maggot producers, only a minority extracted larvae from production residues. These extractions were done manually by scraping the residue until the maggots were exposed at the bottom of the container. Sometimes perforated clay pots were used. More than half of maggot producers claimed that the quantities produced

Table 2. Maggot production materials and methods in rural areas.

\begin{tabular}{|c|c|c|c|c|c|}
\hline $\begin{array}{l}\text { Categories of } \\
\text { substrates }\end{array}$ & Substrates & $\begin{array}{l}\text { Initial state of } \\
\text { substrate }\end{array}$ & Attractants & Water use & $\begin{array}{l}\text { Number of } \\
\text { production days }{ }^{1}\end{array}$ \\
\hline \multirow[t]{3}{*}{$\begin{array}{l}\text { Manures } \pm^{2} \text { cereal } \\
\text { bran }\end{array}$} & $\begin{array}{l}\text { poultry manure } \pm \text { rice bran } \\
\text { cattle manure } \pm \text { rice or maize } \\
\text { bran }\end{array}$ & $\begin{array}{l}\text { dry } \\
\text { fresh or dry }\end{array}$ & $\begin{array}{l}\text { no } \\
\pm \text { fruits waste (mango } \\
\text { and shea pulp) or } \\
\text { animal blood }\end{array}$ & $\begin{array}{l}\text { yes } \\
\text { yes if the substrate is } \\
\text { not wet enough }\end{array}$ & $\begin{array}{l}3 \text { to } 4 \\
3 \text { to } 7\end{array}$ \\
\hline & $\begin{array}{l}\text { cattle manure }+ \text { goats manure } \\
\text { pig manure } \pm \text { litter }\end{array}$ & $\begin{array}{l}\text { dry (powder) } \\
\text { fresh or dry }\end{array}$ & $\begin{array}{l}\text { no } \\
\text { no }\end{array}$ & $\begin{array}{l}\text { yes } \\
\text { yes if the substrate is } \\
\text { not wet enough }\end{array}$ & $\begin{array}{l}5 \text { to } 10 \\
3 \text { to } 5 \text { and even } 10\end{array}$ \\
\hline & $\begin{array}{l}\text { biogas effluent + maize or millet or } \\
\text { sorghum bran }\end{array}$ & fresh & no & $\begin{array}{l}\text { yes if the substrate is } \\
\text { not wet enough }\end{array}$ & 5 to 7 \\
\hline \multirow{6}{*}{$\begin{array}{l}\text { Slaughter wastes } \\
\pm \text { agro-industrial } \\
\text { waste or manures } \\
\text { or cereal bran }\end{array}$} & $\begin{array}{l}\text { cattle rumen content } \pm \text { traditional } \\
\text { brewery waste }\end{array}$ & fresh & \pm animal blood & $\begin{array}{l}\text { yes if the substrate is } \\
\text { not wet enough }\end{array}$ & 3 to 10 \\
\hline & sheep rumen content & fresh & \pm animal blood & $\begin{array}{l}\text { yes if the substrate is } \\
\text { not wet enough }\end{array}$ & 3 to 5 \\
\hline & goat rumen content & fresh & \pm animal blood & $\begin{array}{l}\text { yes if the substrate is } \\
\text { not wet enough }\end{array}$ & 3 to 7 \\
\hline & pig offal & fresh & no & $\begin{array}{l}\text { yes if the substrate is } \\
\text { not wet enough }\end{array}$ & 3 to 4 \\
\hline & animal blood & fresh & no & yes & 5 to 10 \\
\hline & $\begin{array}{l}\text { fish offal and scales } \pm \text { cattle } \\
\text { manure or maize bran }\end{array}$ & fresh & no & $\begin{array}{l}\text { yes if the substrate is } \\
\text { not wet enough }\end{array}$ & $\approx 2$ to 7 \\
\hline \multirow[t]{2}{*}{$\begin{array}{l}\text { Agro-industrial waste } \\
\pm \text { slaughter wastes }\end{array}$} & $\begin{array}{l}\text { traditional brewery waste } \pm \text { cattle } \\
\text { rumen content }\end{array}$ & fresh & $\begin{array}{l} \pm \text { fish offal and scales or } \\
\text { animal blood }\end{array}$ & $\begin{array}{l}\text { yes if the substrate is } \\
\text { not wet enough }\end{array}$ & 3 to 7 and even 14 \\
\hline & cottonseed cake & dry & no & yes & 5 to 6 \\
\hline $\begin{array}{l}\text { Cereal bran } \pm \\
\text { slaughter wastes or } \\
\text { manures }\end{array}$ & $\begin{array}{l}\text { maize bran } \pm \text { fish offal and scales } \\
\text { rice bran + cattle manure }\end{array}$ & $\begin{array}{l}\text { dry } \\
\text { dry }\end{array}$ & $\begin{array}{l}\text { traditional brewery waste } \\
\text { no }\end{array}$ & $\begin{array}{l}\text { yes } \\
\text { yes }\end{array}$ & $\begin{array}{l}\approx 7 \\
\approx 5\end{array}$ \\
\hline Mixed & kitchen waste and food left-overs & fresh & rotten fruits and pulp & yes & 4 to 5 \\
\hline
\end{tabular}


were insufficient relative to the quantity of substrates and the size of their flock.

\section{Main fly species involved in the decomposition of potential substrates}

The respondents identified the fly larvae that develop in decomposing organic residues by size, general appearance, colour, mouthparts, and development time. Three main types of fly larvae were identified as very common in the decomposition of the different substrates (Table 3). These include the larvae of the housefly, which probably also contained flies of the family Calliphoridae, the black soldier fly and the fruit flies of the family Tephritidae (Bactrocera spp., Ceratitis spp., Dacus spp.) that were found only in rotten mango fruits from orchards. Housefly larvae were cited as colonising all the listed organic residues contrary to the black soldier fly (Table 3). Black soldier fly was cited or described by $13.61 \%$ of the farmers. According to the poultry farmers, these three types of larvae are commonly consumed by poultry when scavenging or when they were deliberately provided. Farmers have mentioned that getting the larvae of the black soldier fly was difficult because of the length of its development which is longer (around one to two weeks) than those of the house fly or Calliphoridae. Animal blood, Fish offal and scales and shea fruit (V. paradoxa) pulp have been reported by many poultry farmers as the most favourable substrates for the development of house

Table 3. Main species of maggot found in organic waste.

\begin{tabular}{|c|c|}
\hline Categories of substrates and/or attractants & Substrates \\
\hline Manures & $\begin{array}{l}\text { poultry manure } \pm \text { litter } \\
\text { pigeon droppings } \pm \text { litter } \\
\text { cattle manure } \pm \text { litter } \\
\text { sheep manure } \pm \text { litter } \\
\text { goat manure } \pm \text { litter } \\
\text { pig manure } \pm \text { litter } \\
\text { rabbit manure } \pm \text { litter } \\
\text { human manure } \\
\text { biogas effluent }\end{array}$ \\
\hline Slaughter wastes & $\begin{array}{l}\text { cattle rumen content } \\
\text { sheep rumen content } \\
\text { goat rumen content } \\
\text { pig offal } \\
\text { animal blood } \\
\text { fish offal and scales }\end{array}$ \\
\hline Cereal bran & $\begin{array}{l}\text { millet bran } \\
\text { maize bran } \\
\text { sorghum bran } \\
\text { fonio bran } \\
\text { rice bran } \\
\text { wheat bran }\end{array}$ \\
\hline Agro-industrial waste & $\begin{array}{l}\text { cottonseed cake } \\
\text { cotton ginnery waste } \\
\text { traditional brewery waste } \\
\text { filtrate from the fermentation of Parkia biglobosa seeds } \\
\text { filtrate from the fermentation of Hibiscus sabdariffa seeds } \\
\text { sludge from shea butter processing } \\
\text { shea fruit (Vitellaria paradoxa) pulp }\end{array}$ \\
\hline Fermented fruits & $\begin{array}{l}\text { rotten mango fruits from orchards } \\
\text { rotten cashew fruits from orchards } \\
\text { rotten papaya fruits from orchards } \\
\text { rotten banana fruits from orchards }\end{array}$ \\
\hline $\begin{array}{l}\text { Mixed } \\
\text { Others }\end{array}$ & $\begin{array}{l}\text { kitchen waste and food left-overs } \\
\text { vegetable garden wastes }\end{array}$ \\
\hline
\end{tabular}

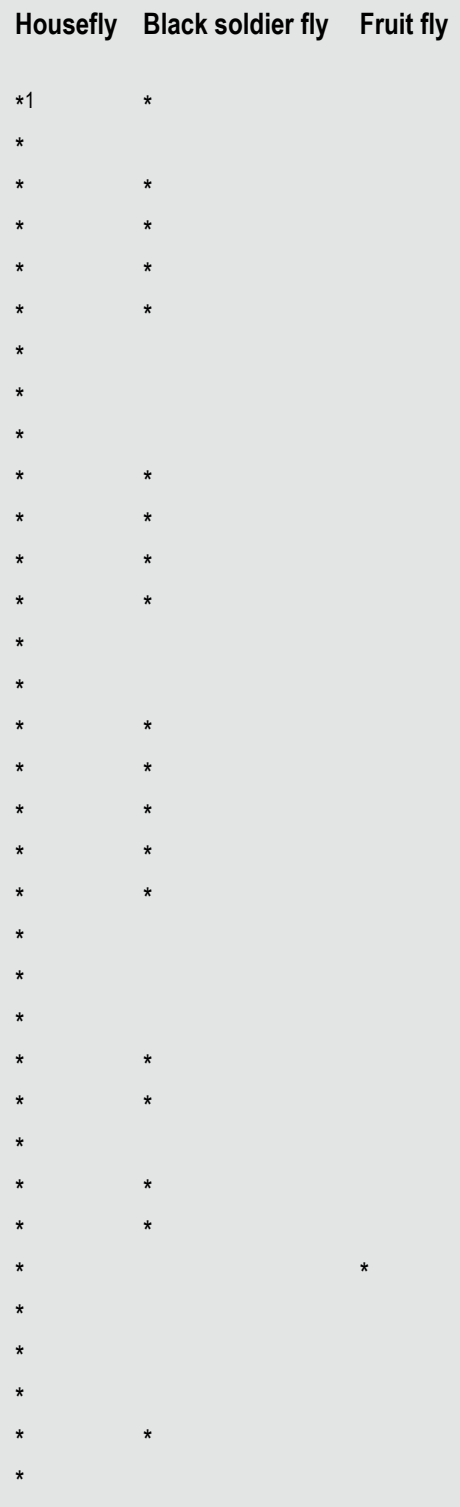

${ }^{1}$ Present. 
flies. However, the residues of traditional brewery waste and cattle manure were cited as the most favourable for black soldier flies.

\section{Discussion}

\section{Importance of feed inputs in traditional poultry feed}

Poultry feed in the investigated regions is mainly based on cereal grains. But a multitude of feeds are exploited including termites and, to a much lower extent, maggots. Termites were commonly cited by respondents as a supplementary or occasional feed, mainly for the young birds. These observations were also documented in other studies in West Africa (e.g. Caparros Megido et al., 2015; Hien et al., 2005). A recent study in Burkina Faso showed that $78 \%$ of smallholder farmers give termites to their poultry at least occasionally (Sankara et al., 2018). Many constraints associated to the exploitation of termites have been mentioned by respondents, such as long distances to be covered for termite collection, insufficient quantities available, and disappearance of termite habitats due to the indiscriminate use of synthetic pesticides. Some termites are also reported to harm poultry by causing diseases or even by killing chicks (Tamboura et al., 1998). Fly larvae could represent an alternative but, in the investigated region, only $14.9 \%$ of the respondents mentioned that they at least occasionally produce or collect fly larvae for their poultry. In Benin, Pomalégni et al. (2017) reported that $5.7 \%$ of the farmers produce fly larvae to feed their poultry but they did not include farmers that simply collect them.

\section{Substrates available and used for fly larvae production}

About 30 organic residues have been identified as available for producing fly larvae (Table 1). These are essentially residues from many common activities such as crop production, animal husbandry, trade and fishing. Most of these organic residues have also been recorded as potential substrates for fly production in Benin (Pomalégni et al., 2016). Poultry manure was the most available waste because all households surveyed raised poultry. However, access to poultry manure is not always easy because of the scavenging behaviour of poultry. In rural areas, the majority of poultry farmers allow animals to scavenge for food (Ouédraogo et al., 2015a; Pousga and Boly, 2009). The work of Gomgnimbou (2015) has also shown that, in urban and peri-urban areas of Bobo-Dioulasso, poultry manure was inaccessible due to lack of storage facilities. Beyond the problem of access, poultry farmers use them as organic fertiliser or market them for such.

Most of the identified substrates were rarely used for the production or harvesting of maggots. This result may reveal a relative ignorance of potential substrates for maggot productions or suitable production techniques. Animal blood, rumen content of cattle, sheep, and goats were the substrates and/or attractants mostly used as source to obtain maggots despite their low availability. These wastes were bought from traditional or modern slaughterhouses. The low availability of inputs was closely related to the fact that fewer animals were slaughtered in the villages. Indeed, villages that owned functional abattoirs were few but hosted most fly larvae producers.

In Benin, the most utilised substrates by farmers for the production of housefly larvae were soy and maize bran and pig and chicken manure (Pomalégni et al., 2017). In Burkina Faso, these and other substrates that are potentially highly suitable for feeding larvae are primarily used for other purposes such as soil fertilisation, human and animal feed and pharmaceutical use (Jayathilakan et al., 2012). In particular, several available substrates are directly given to poultry: fish offal and scales; vegetable crops' residues and shea fruit (V. paradoxa) pulp; cereal bran (millet, maize, sorghum, fonio, rice, wheat); cottonseed cake; orchard residues (mango, papaya, banana); and kitchen waste and food left-overs (tubers, vegetables and fruits) (Ayssiwede et al., 2013; Ouédraogo et al., 2015a).

\section{Practices related to the production of maggots}

The variability of the number of days of production and use of attractants depended on the substrates, the species of fly larvae produced and the period of the year. Indeed, according to the poultry farmers, the warm periods allowed a more rapid production while the cold ones were very unfavourable for the production of maggots. Temperature, humidity and seasons are known to an impact on the production of maggots (Bouafou, 2011). In Mali, Koné et al. (2017) also observed high variations in yield between seasons, the rainy season being most favourable and the dryhot season the least favourable. With favourable substrates, maggots can their maximum size in the $4^{\text {th }}$ day (Bouafou et al., 2006). In Mali, larvae were even collected after three days (Koné et al., 2017). In our survey, farmers mentioned production time ranging from three to 14 days, but long development times were surely related to black soldier flies.

The quality of the organic substrates is known to influence the larval development rate and yields (Kenis et al., 2018; Pastor et al., 2015). The fermentation of substrates was suggested by farmers to increase their quality, particularly for cereal bran and cattle manure. On the other hand, Koné et al. (2017) mentioned that poultry manure should be stored dry and moistened only the day of exposure to fly oviposition. 


\section{Main fly species involved in the decomposition of potential substrates}

The housefly, black soldier fly and fruit flies were identified by poultry farmers as the most commonly found in the organic residues. Houseflies and black soldier flies are increasingly used for the bioconversion of organic wastes worldwide (Kenis et al., 2018; Pastor et al., 2015; Van Huis et al., 2013). It is particularly notable that $13.6 \%$ of the farmers mentioned black soldier fly in this survey since it was previously thought that this exotic fly of American origin has no tradition as animal feed in Africa (Kenis et al., 2014).

\section{Conclusions}

This study highlights the potential of substrates and attractants for maggot production by traditional poultry farmers in West Africa, despite constraints related to their availability and accessibility. The survey provides information on production techniques of maggots and current feeding practices in two regions of Burkina Faso. Sustainable production methods adapted to the rural environment and a precise determination of the most productive substrates will be useful for poultry farmers. In addition, the safety of the production techniques will need to be assessed before further dissemination.

\section{Acknowledgements}

We thank all the respondents of the survey. This study was carried out as part of the project 'IFWA - Sustainable use of insects to improve livestock production and food security in smallholder farms in West Africa, funded by the Swiss Agency for Development and Cooperation and the Swiss National Science Foundation, in the framework of the Swiss Programme for Research on Global Issues for Development (R4D). Marc Kenis was partly funded though the CABI Development Fund (supported by contributions from the Australian Centre for International Agricultural Research, the UK's Department for International Development, and others).

\section{Supplementary material}

Supplementary material can be found online at https://doi. org/10.3920/JIFF2018.0004.

Supplementary Material S1. Questionnaire.

\section{References}

Ayssiwede, S.B., Dieng, A., Houinato, M.R.B., Chrysostome, C.A.A.M., Issay, I., Hornick, J.-L. and Missohou, A., 2013. Elevage des poulets traditionnels ou indigènes au Sénégal et en Afrique subsaharienne: état des lieux et contraintes. Annale de Médecine Vétérinaire 157: 103-119.

Barre, A., Rougé, P., Caze-Subra, S., Gironde, C., Bienvenu, F. and Bienvenu, J., 2014. Entomophagie et risque allergique. Revue Française d'Allergologie 4356: 287-343.

Boko, K.C., Kpodekon, T.M., Dahouda, M., Marlier, D. and Mainil, J.G., 2006. Contraintes techniques et sanitaires de la production traditionnelle de pintade en Afrique subsaharienne. Annale de Médecine Vétérinaire 156: 25-36.

Bouafou, K.G.M., 2011. Revue bibliographique sur les asticots et leur emploi dans l'alimentation animale. Journal of Animal and Plant Sciences 12: 1543-1551.

Bouafou, K.G.M., Kouame, K.G., Amoikon, K.E. and Offoumou, A.M., 2006. Potentiel pour la production d'asticots sur des sous-produits en Côte d'Ivoire. Tropicultura 24: 157-161.

Caparros Megido, R., Alabi, T., Larreché, S., Alexandra, L., Haubruge, E. and Francis, F., 2015. Risques et valorisation des insectes dans l'alimentation humaine et animale. Annales de la Société Entomologique de France 51: 215-258.

Dahouda, M., Toléba, S.S., Senou, M., Youssao, A.K.I., Hambuckers, A. and Hornick, J.-L., 2009. Les ressources alimentaires nonconventionnelles utilisables pour la production aviaire en Afrique: valeurs nutritionnelles et contraintes. Annale de Médecine Vétérinaire 153: 5-21.

Direction Générale des Etudes et des Statistiques Sectorielles (DGESS), 2015. Annuaire des statistiques de l'élevage 2013-2014. DGESS, Ministère des Ressources Animales, Ouagadougou, Burkina Faso, $177 \mathrm{pp}$.

Food and Agriculture Organisation (FAO), 2008. Revue du secteur avicole: Burkina Faso. FAO, Rome, Italy, 43 pp.

Gomgnimbou, A.P.K., 2015. Valorisation agronomique des substrats organiques d'origine animale dans la zone urbaine et périurbaine de Bobo-Dioulasso (Burkina Faso). PhD thesis, Université Polytechnique de Bobo-Dioulasso (UPB), Bobo-Dioulasso, Burkina Faso, 236 pp.

Hardouin, J. and Mahoux, G., 2003. Zootechnie d'insectes - élevage et utilisation au bénéfice de l'homme et de certains animaux. Bureau pour l'Echange et la Distribution de l'Information sur le MiniElevage (BEDIM), Gembloux, Belgique, $164 \mathrm{pp}$.

Hien, O.C., Diarra, B., Drabo, Y., Boly, H. and Sawadogo, L., 2005. Pratiques de l'aviculture traditionnelle par les différents groupes ethniques de la région des cascades au Burkina Faso. Agronomie Africaine 17: 227-239.

Institut National de la Statistique et de la Démographie (INSD), 2008. Recensement général de la population et de l'habitation de 2006: résultats définitifs. INSD, Ministère de l'Economie et des Finances, Ouagadougou, Burkina Faso, 52 pp.

Jayathilakan, K., Sultana, K., Radhakrishna, K. and Bawa, A.S., 2012. Utilization of byproducts and waste materials from meat, poultry and fish processing industries. Journal of Food Science and Technology 49: 278-293. 
Kenis, M., Bouwassi, B., Boafo, H., Devic, E., Han, R., Koko, G., Koné, N'G., Maciel-Vergara, G., Nacambo, S., Pomalégni, S.C.B., Roffeis, M., Wakefield, M., Zhu, F. and Fitches, E., 2018. Small-scale fly larvae production for animal feed. In: Halloran, A., Flore, R., Vantomme, P. and Roos, N. (eds.) Edible insects in sustainable food systems. Springer, Cham, Switzerland, pp. 239-261.

Kenis, M., Koné, N., Chrysostome, C.A.A.M., Devic, E., Koko, G.K.D., Clottey V.A., Nacambo, S. and Mensah, G.A., 2014. Insects used for animal feed in West Africa. Entomologia 2(218): 107-114.

Koné, N'G., Sylla, M., Nacambo, S. and Kenis, M., 2017. Production of housefly larvae for animal feed through natural oviposition. Journal of Insects as Food and Feed 3: 177-186.

Loa, C., 2000. Production et utilisation contrôlées des asticots. Tropicultura 18: 215-219.

Makkar, H.P.S., Tran, G., Heuzé, V. and Ankers, P., 2014. State-ofthe-art on use of insects as animal feed. Animal Feed Science and Technology 197: 1-33.

Odesanya, B.O., Ajayi, S.O., Agbaogun, B.K.O. and Okuneye, B., 2011. Comparative Evaluation of nutritive value of maggots. International Journal of Scientific and Engineering Research 2(11): 1-5.

Ouattara, S., Bougouma-Yameogo, V.M.C., Nianogo, A.J. and Ouedraogo, H., 2014. Effets de la substitution des graines torréfiées de soja (Glycine max) par celles de niébé (Vigna unguiculata) et du niveau de protéines alimentaires sur les performances zootechniques et la rentabilité économique de lélevage de poulets de race locale (Gallus gallus) au Burkina Faso. Revue d'Élevage et de Médecine Vétérinaire des Pays Tropicaux 67: 23-33.

Ouédraogo, B., Bale, B., Zoundi, S.J. and Sawadogo, L., 2015a. Caractéristiques de l'aviculture villageoise et influence des techniques d'amélioration sur ses performances zootechniques dans la province du Sourou, région Nord-Ouest Burkinabè. International Journal of Biological and Chemical Sciences 9: 1528-1543.

Ouédraogo, B., Gnanda, I.B., Sanfo, R., Zoundi, S.J. and Bayala, B., 2015b. Etude comparative des performances réalisées avec l'incorporation de la farine de co-produits de volaille et la farine des asticots dans des rations de poulets de chair au Burkina Faso. Revue Ivoirienne des Sciences et Technologies 25: 148-161.

Pastor, B., Velasquez, Y., Gobbi, P. and Rojo, S., 2015. Conversion of organic wastes into fly larval biomass: bottlenecks and challenges. Journal of Insects as Food and Feed 1: 179-193.

Pomalégni, S.C.B., 2017. Perceptions, performances zootechniques et qualité nutritionnelle de la viande de poulets locaux (Gallus gallus) nourris avec des rations alimentaires à base de larves de mouche (Musca domestica, Linnaeus 1758) au Bénin. PhD thesis, University of Abomey-Calavi, Abomey-Calavi, Benin.
Pomalégni, S.C.B., Gbemavo, D.S.J.C., Kpade, C.P., Babatounde, S., Chrysostome, C.A.A.M., Koudande, O.D., Kenis, M., Glèlè, K.R.L. and Mensah, G.A., 2016. Perceptions et facteurs déterminant l'utilisation des asticots dans l'alimentation des poulets locaux (Gallus gallus) au Bénin. Journal of Applied Biosciences 98: 9330-9343.

Pomalégni, S.C.B., Gbemavo, D.S.J.C., Kpadé, C.P., Kenis, M. and Mensah, G.A., 2017. Traditional use of fly larvae by small poultry farmers in Benin. Journal of Insects as Food and Feed 3: 187-192.

Pousga, B. and Boly H., 2009. Synthèse des travaux de recherche en aviculture au Burkina Faso. Aviculture Familiale 18(1-2): 28-35.

Pousga, S., 2007. Supplementation strategies for semi-scavenging chickens in Burkina Faso: evaluation of some local feed resources. $\mathrm{PhD}$ thesis, Swedish University of Agricultural Sciences, Uppsala, Sweden, 116 pp.

Pousga, S., Boly, H., Lindberg, J.E., and Ogle, B., 2005. Scavenging pullets in Burkina Faso: effect of season, location and breed on feed and nutrient intake. Tropical Animal Health and Production 37: 623-634.

Roffeis, M., Almeida, J., Wakefield, M.E., Valada, T.R.A., Devic, E., Koné, N., Kenis, M., Nacambo, S., Fitches, E.C., Koko, G.K.D., Mathijs, E., Achten, W.M.J. and Muys, B., 2017. Life cycle inventory analysis of prospective insect based feed production in West Africa. Sustainability 9: 1697.

Sankara, F., Pousga, S., Dao, N.C., Gbemavo, D.S.J.C, Clottey, V.A., Coulibaly, K., Nacoulma, J.P., Ouedraogo, S. and Kenis, M., 2018. Indigenous knowledge and potential of termites as poultry feed in Burkina Faso. Journal of Insects as Food and Feed, 4: 211-218.

Tamboura, H., Kaboré, H. and Yaméogo, S.M., 1998. Ethnomédecine vétérinaire et pharmacopée traditionnelle dans le plateau central du Burkina Faso: cas de la province du Passoré. Biotechnologie, Agronomie, Societé et Environnement 2: 181-191.

Thiombiano, A. and Kampmann, D., 2010. Biodiversity atlas of West Africa. Vol. 2. Burkina Faso. BIOTA, Ouagadougou, Burkina Faso and Frankfurt am Main, Germany, 625 pp.

Van Huis, A., Van Itterbeeck, J., Klunder, H., Mertens, E., Halloran, A., Muir, G. and Vantomme, P., 2013. Edible insects: future prospects for food and feed security. FAO Forestry Paper no. 171. Food and Agriculture Organization of the United Nations (FAO), Rome, Italy, 187 pp. Available at: http://www.fao.org/docrep/018/i3253e/ i3253e.pdf.

Zhou, F., Tomberlin, J.K., Zheng, L., Yu, Z. and Zhang, J., 2013. Developmental and waste reduction plasticity of three black soldier fly strains (Diptera: Stratiomyidae) raised on different livestock manures. Journal of Medical Entomology 50: 1224-1230. 